\title{
The Impact of Antibiotics on Prognosis of Metastatic Renal Cell Carcinoma in Japanese Patients Treated With Immune Checkpoint Inhibitors
}

\author{
KOSUKE UEDA $^{1,2}$, SATORU YONEKURA ${ }^{2}$, NAOYUKI OGASAWARA ${ }^{1}$, YOSHIHIRO MATSUNAGA ${ }^{1}$, \\ RYUJI HOSHINO ${ }^{1}$, HIROFUMI KUROSE ${ }^{1}$, KATSUAKI CHIKUI $^{1}$, KEIICHIRO UEMURA ${ }^{1}$, MAKOTO NAKIRI $^{1}$, \\ KIYOAKI NISHIHARA ${ }^{1}$, MITSUNORI MATSUO ${ }^{1}$, SHIGETAKA SUEKANE ${ }^{1}$ and TSUKASA IGAWA ${ }^{1}$ \\ ${ }^{1}$ Department of Urology, Kurume University School of Medicine, Kurume, Japan; \\ ${ }^{2}$ Gustave Roussy Cancer Campus, Villejuif, France
}

\begin{abstract}
Background/Aim: The present study aimed to examine the influence of antibiotics $(A B)$ on the clinical outcomes of Japanese patients treated with immune check point inhibitors (ICIs) for metastatic renal cell carcinoma (RCC) patients. Patients and Methods: A total of 31 patients with metastatic RCC treated with ICIs from November 2016 to April 2019 were retrospectively reviewed and analyzed. Results: Five patients were treated with $A B$ prior to ICIs treatment. Median progression free survival (PFS) of patients treated with $A B$ vs. patients not treated with $A B$ was 2.8 months and 18.4 months, respectively. The difference between PFS was statistically significant $(p=0.0004)$. In multivariate analyses, $A B$ use $(p=0.0377)$ and presence of immune related adverse events $(p=0.0042)$ were independent prognostic factors for PFS in association with ICIs therapy. Conclusion: The use of $A B$ before ICIs treatment was a predictor of poor ICIs response in metastatic RCC.
\end{abstract}

Immune checkpoint inhibitors (ICIs) that target programmed cell death-1 (PD-1) protein, programmed cell death-ligand 1 protein, and cytotoxic $\mathrm{T}$ lymphocyte-associated antigen 4 (CTLA-4), have changed the therapeutic landscape and are currently standard treatment options in patients with advanced and metastatic renal cell carcinoma (RCC) $(1,2)$. Despite the remarkable success of clinical applications, the efficacy of ICIs in RCC varies greatly across individual patients. Some researchers have reported biomarkers for

Correspondence to: Kosuke Ueda, MD, Ph.D., Department of Urology, Kurume University School of Medicine, 67 Asahi-machi, Kurume 830-0011, Japan. Tel: +81 942317572, Fax: +81 942317866, e-mail: ueda_kousuke@med.kurume-u.ac.jp

Key Words: Renal cell carcinoma, immune checkpoint inhibitor, antibiotics, gut microbiota, progression-free survival. predicting prognosis in patients treated with ICIs, such as PD-L1 and PD-L2 positivity, tumor mutation burden, and profile of immune-related genes (3). Furthermore, the association of immune related adverse events (irAEs) with prognosis in metastatic RCC has been recently reported (4, $5)$. Thus, it is critical to explore reliable predictors to improve prognosis of RCC patients treated with ICIs.

Recently, several studies have demonstrated the crucial impact of human gut microbiota on ICIs therapies (6-9). It is well recognized that antibiotics $(\mathrm{AB})$ alter the diversity and composition of gut microbiota and consequently shift their metabolic capacity (10). The hypothesis was that modulation of gut microbiota by $\mathrm{AB}$ may be associated with poor response to ICIs. However, the data on the association between $\mathrm{AB}$ use and clinical outcomes with ICIs are limited, especially in Japanese patients with genitourinary cancer.

In the present study, we performed a retrospective analysis to examine the influence of $\mathrm{AB}$ on the clinical outcomes of Japanese patients treated with ICIs therapy for metastatic RCC patients.

\section{Patients and Methods}

Study design and patients. We retrospectively examined clinical information collected from 31 RCC patients treated with ICIs at Kurume University Hospital from November 2016 to April 2019. All patients received nivolumab or the combination of nivolumab and ipilimumab. Nivolumab was intravenously administered at $3 \mathrm{mg} / \mathrm{kg}$ or $240 \mathrm{mg} /$ body every 2 weeks. Nivolumab and ipilimumab were administered intravenously at a dose of $240 \mathrm{mg} / \mathrm{body}$ and $1 \mathrm{mg} / \mathrm{kg}$, respectively, every 3 weeks in four doses (induction phase), followed by nivolumab monotherapy at a dose of $240 \mathrm{mg} /$ body every 2 weeks (maintenance phase). Dose reductions were not permitted for any reason. However, the dose interval could be modified according to the patient condition.

The irAEs included cutaneous, gastrointerstinal, endocrine, pulmonary, hepatobiliary, pancreatitis (elevated pancreatic enzymes), and ocular toxicity according to previous studies (5). The severity of 
Table I. Baseline characteristics of patients.

\begin{tabular}{|c|c|c|c|c|}
\hline Feature & Total $(n=31)$ & $\mathrm{AB}(\mathrm{n}=5)$ & No AB $(n=26)$ & $p$-Value \\
\hline Age, years, range & $67(44-80)$ & $67(46-68)$ & $68(44-80)$ & 0.4043 \\
\hline \multicolumn{5}{|l|}{ Gender, n (\%) } \\
\hline Male & $24(77.4)$ & $4(80.0)$ & $20(76.9)$ & \multirow[t]{2}{*}{0.8788} \\
\hline Female & $7(22.6)$ & $1(20.0)$ & $6(23.1)$ & \\
\hline BMI $\left(\mathrm{kg} / \mathrm{m}^{2}\right)$, median & 20.8 & 20.9 & 19.3 & 0.6868 \\
\hline \multicolumn{5}{|l|}{ Prior nephrectomy, n (\%) } \\
\hline Yes & $27(87.1)$ & $3(60.0)$ & $24(92.3)$ & \multirow[t]{2}{*}{0.0828} \\
\hline No & $4(12.9)$ & $2(40.0)$ & $2(7.7)$ & \\
\hline \multicolumn{5}{|l|}{ Performance status, n (\%) } \\
\hline 0,1 & $28(90.3)$ & $4(80.0)$ & $24(92.3)$ & \multirow[t]{2}{*}{0.4362} \\
\hline$\geq 2$ & $3(9.7)$ & $1(20.0)$ & $2(7.7)$ & \\
\hline \multicolumn{5}{|l|}{ Histological subtype, n (\%) } \\
\hline Clear cell type & $27(87.1)$ & $3(60.0)$ & $24(92.3)$ & \multirow[t]{3}{*}{0.2221} \\
\hline Papillary type & $2(6.5)$ & $1(20.0)$ & $1(3.8)$ & \\
\hline unknown & $2(6.5)$ & $1(20.0)$ & $1(3.8)$ & \\
\hline \multicolumn{5}{|c|}{ IMDC risk classification, $\mathrm{n}(\%)$} \\
\hline Favorable & $3(9.7)$ & $0(0.0)$ & $3(11.5)$ & \multirow[t]{3}{*}{0.5098} \\
\hline Intermediate & $20(64.5)$ & $4(80.0)$ & $16(61.5)$ & \\
\hline Poor & $8(25.8)$ & $1(20.0)$ & $7(26.9)$ & \\
\hline \multicolumn{5}{|c|}{ Number of prior regimens, $\mathrm{n}(\%)$} \\
\hline 0 & $3(9.7)$ & $1(20.0)$ & $2(7.7)$ & \multirow[t]{3}{*}{0.3362} \\
\hline 1 & $13(41.9)$ & $3(60.0)$ & $10(38.5)$ & \\
\hline$\geq 2$ & $15(48.4)$ & $1(20.0)$ & $14(53.8)$ & \\
\hline \multicolumn{5}{|l|}{ Treatment, n (\%) } \\
\hline Nivolumab & $28(90.3)$ & $4(80.0)$ & $24(92.3)$ & \multirow[t]{2}{*}{0.4362} \\
\hline Ipilimumab + Nivolumab & $3(9.7)$ & $1(20.0)$ & $2(7.7)$ & \\
\hline \multicolumn{5}{|l|}{ irAE, n (\%) } \\
\hline Present & $11(35.5)$ & $0(0.0)$ & $11(42.3)$ & \multirow[t]{2}{*}{0.0269} \\
\hline Absent & $20(64.5)$ & $5(100.0)$ & $15(57.7)$ & \\
\hline
\end{tabular}

AB: Antibiotics; BMI: body mass index; IMDC: International Metastatic Renal Cell Carcinoma Database Consortium; irAE: immune related adverse events.

irAEs was graded according to Common Terminology Criteria for Adverse Events (CTCAE) version 4.0 (11). Radiological evaluations were performed for all patients by computed tomography (CT). Tumor response was evaluated as best response according to the Response Evaluation Criteria in Solid Tumours (RECIST) version 1.1 (12).

We defined patients who received any oral or intravenous $\mathrm{AB}$ within 30 days before ICIs treatment as the $\mathrm{AB}$ group as previously reported (8). PFS was measured from the time of ICI initiation to clinical or radiographic progression or death from any cause. OS was measured from the time of ICIs initiation to death from any cause.

Statistical analysis. Kaplan-Meier curves were generated for progression free survival (PFS) and overall survival (OS). Comparison of PFS and OS among groups was achieved via logrank test. The relationships between groups were compared using Chi-squared test, Fisher's exact test or Student's $t$-test. Cox proportional hazard model was used for univariate and multivariate analyses to calculate the hazard ratio (HR) and $95 \%$ confidence interval (CI). The variables with $p$-values $<0.1$ identified in univariate analyses were selected for multivariate analyses. All statistical analyses were performed using JMP version 13 (SAS Institute, Inc., Cary, NC, USA). All $p$-values were two-sided, statistical significance was set at $p<0.05$.
Ethical approval. This study was conducted in full accordance with the World Medical Association Declaration of Helsinki and was independently reviewed and approved by the Ethics Review Committee at Kurume University School of Medicine. Patients were not solicited for informed consent, given the retrospective nature of our study. All patient data were processed in anonymity and deidentified prior to analysis.

\section{Results}

Patients characteristics. The clinicopathological characteristics of the 31 study participants are summarized in Table I. All patients had metastatic RCC and received ICIs therapy. Nearly all patients $(28 / 31,90.3 \%)$ received nivolumab monotherapy after 1 or more molecular targeted therapies. Three patients $(9.7 \%)$ received the combination of nivolumab and ipilimumab as first line therapy. Of the 31 patients, 5 patients $(16.1 \%)$ received $\mathrm{AB}$ within 30 days of initiating ICIs therapy. $\mathrm{AB}$ were prescribed for infection in the upper respiratory tract, urinary tract, and skin or acute cholangitis. All of them were prescribed $\beta$-Lactums inhibitors. Clinicopathological characteristics 
Table II. Profile of immune related adverse events (irAEs).

\begin{tabular}{lll}
\hline irAE categories & \multicolumn{2}{c}{$\mathrm{n}=31$} \\
\cline { 2 - 3 } & $\begin{array}{l}\text { All Grades } \\
(\mathrm{n}=11)(\%)\end{array}$ & $\begin{array}{l}\text { Grade } \geq 3 \\
(\mathrm{n}=3)(\%)\end{array}$ \\
\hline Rash/pruritus & $7(63.6)$ & $0(0.0)$ \\
Elevated hepatic enzymes & $3(27.2)$ & $1(33.3)$ \\
Interstitial pneumonia & $2(18.2)$ & $0(0.0)$ \\
Colitis & $1(9.1)$ & $0(0.0)$ \\
Adrenal insufficiency & $1(9.1)$ & $1(33.3)$ \\
Elevated pancreatic enzymes & $1(9.1)$ & $1(33.3)$ \\
Uveitis & $1(9.1)$ & $0(0.0)$ \\
\hline
\end{tabular}

between $\mathrm{AB}$ group and no $\mathrm{AB}$ group were well balanced, except that no patients in the AB group had experienced irAEs upon ICIs therapy $(p=0.0269)$. However, there was no significant difference in heamatological and biochemical analysis between $\mathrm{AB}$ and no $\mathrm{AB}$ group.

irAEs profile of ICIs therapy. Of the 31 patients, 11 patients (35.5\%) experienced irAEs. Most irAEs were grade 1 or 2 (Table II). Cutaneous irAEs such as rash and pruritus were the most frequent $(7 / 11,63.6 \%)$, followed by elevated hepatic enzymes and interstitial pneumonia. One patient in each group experienced Grade 3 or higher elevated hepatic enzymes, adrenal insufficiency and elevated pancreatic enzymes. However, there was no case of treatment-related death in this study.

Best overall response according to $A B$ use. Figure 1 shows patients' ratio regarding the best overall response during ICIs therapy. Complete response was not obtained as best response to ICIs therapy in our study. The objective response rate (ORR) tended to be higher in patients without $A B$ than in those with $\mathrm{AB}$. However, there was no statistically significant difference between these two groups $(p=0.0926)$.

Clinical course according to $A B$ use. Figure 2 shows the estimated curves of PFS and OS according to AB use. Median $\mathrm{PFS}$ in patients treated with $\mathrm{AB}$ vs. patients not treated with $\mathrm{AB}$ were 2.8 months $[95 \%$ confidence interval $(\mathrm{CI})=1.6-5.6]$ and 18.4 months $(95 \% \mathrm{CI}=6.5$-not reached), respectively ( $p=0.0004$, log-rank test) (Figure 2A). Median OS was not significantly different between those with $\mathrm{AB}$ and those without $\mathrm{AB}$ (not reached for both groups). Nivolumab monotherapy after second line treatment was also examined, and the PFS of patients with $\mathrm{AB}$ was significantly inferior compared to that without $\mathrm{AB}$ ( $p=0.0023$, data no shown).

To identify the prognostic factors for ICIs treatment associated with PFS, univariate and multivariate analyses were

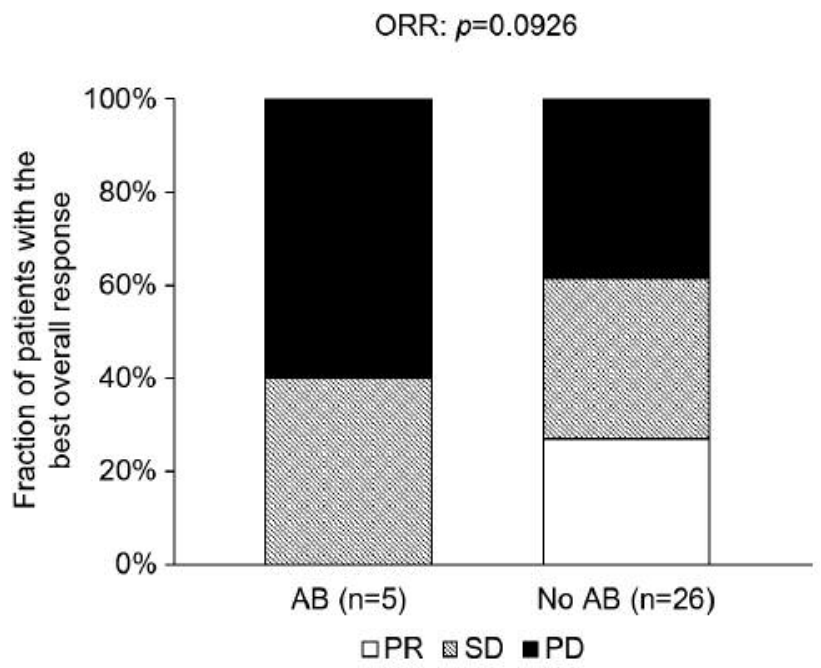

Figure 1. Best overall response to immune checkpoint inhibitors therapy. The objective response rate tended to be higher in patients who did not receive antibiotics $(A B)$ than in those who received $A B$.

performed using the Cox proportional hazards model (Table III). Univariate analyses showed that $\mathrm{AB}$ use [hazard ratio $(\mathrm{HR})=6.518,95 \% \mathrm{CI}=1.857-21.416, p=0.0048]$ and the presence of irAEs $(\mathrm{HR}=0.122,95 \% \mathrm{CI}=0.019-0.443 p=0.0006)$ were significant factors affecting PFS. Furthermore, multivariate analyses also identified $\mathrm{AB}$ use $(\mathrm{HR}=3.830,95 \% \mathrm{CI}=1.086$ $12.717 ; p=0.0377)$ and presence of irAEs $(\mathrm{HR}=0.149$, $95 \% \mathrm{CI}=0.023-0.574, p=0.0042)$ as independent prognostic factors for PFS in association with ICIs therapy (Table III).

\section{Discussion}

This retrospective study showed that PFS after initiation of ICIs therapy was significantly shorter in patients who received $\mathrm{AB}$ within 30 days before initiating ICIs treatment than in those who did not receive $A B$. No significant association between $\mathrm{AB}$ use and $\mathrm{OS}$ was indicated, although a trend toward the negative influence of $A B$ use on OS was observed. To our knowledge, our study is the first to examine the association of $\mathrm{AB}$ use with poor response to ICIs in Japanese metastatic RCC patients.

The anticancer response of ICIs therapy is enhanced by inhibiting PD-1 or CTLA-4 pathways and then re-activating host immune function $(13,14)$. The gut microbiota is known to play a crucial role in the anticancer response to ICIs treatment. Recently, the number of studies examining the relationship between $\mathrm{AB}$ use and ICIs efficacy has increased $(6-9,15)$. Most of them have shown a negative association between $\mathrm{AB}$ and clinical outcome. Dysbiosis induced by $\mathrm{AB}$ modifies gut microbiota composition, leading to loss of diversity (16, 17). Matson et al. (18) and Gopalakrishnan et 

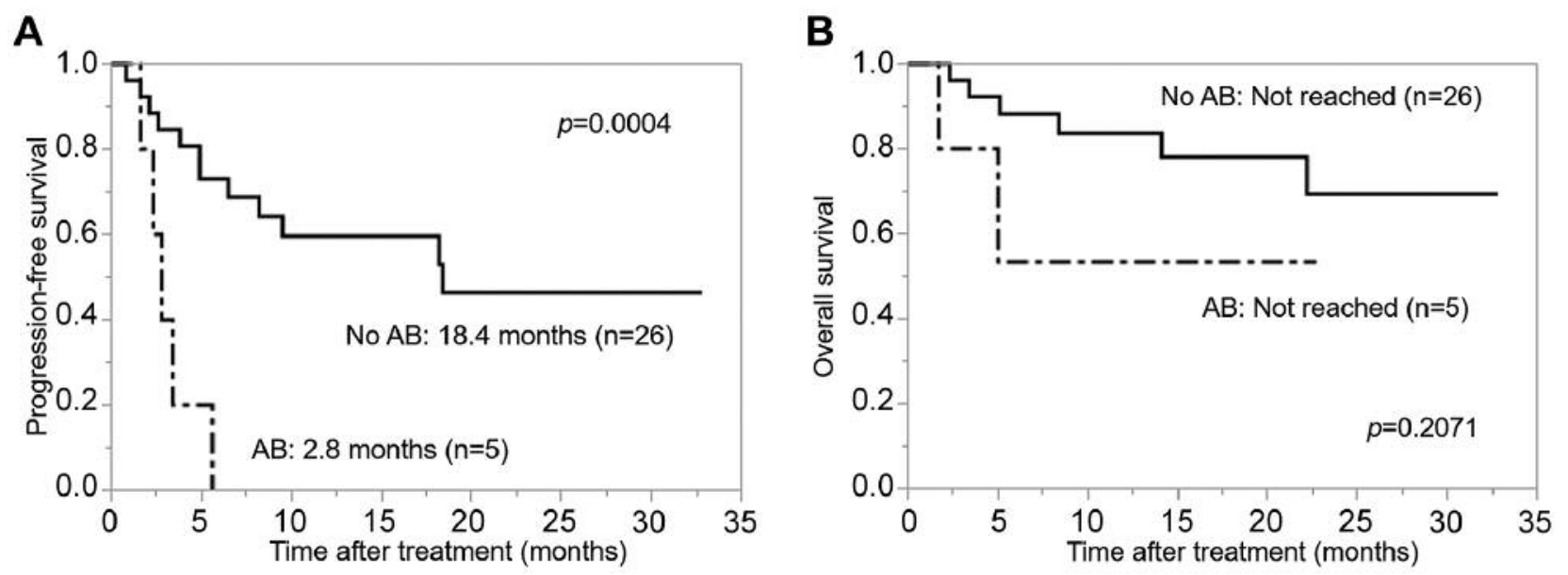

Figure 2. Progression-free survival (A) and overall survival $(B)$ in patients with renal cell carcinoma treated with immune checkpoint inhibitors therapy according to antibiotics use.

al. (19) have demonstrated that bacterial species more abundant in responders to anti-PD-1 therapy included Ruminococcaceae family and Bifidobacterium spp. and reconstitution of germ-free mice with fecal transplantation from responders could lead to improved tumor control, augmented $\mathrm{T}$ cell responses, and greater efficacy of ICIs therapy in metastatic melanoma. Routy et al. (6) have also found that the abundance of Akkermansia muciniphilia was significantly associated with favorable outcomes. Derosa et al. (8) have shown that prior AB use was associated with increased rate of primary progressive disease and worse PFS in patients with RCC treated with ICIs. It has been reported that $\mathrm{AB}$-induced dysbiosis can take 1-3 months to normalize (20). Thereby, they examined the influence of AB use on ICIs therapy at two time points. The results indicated that the effect of $\mathrm{AB}$ use within 60 days before initiating ICIs treatment was less than that of $\mathrm{AB}$ use within 30 days. We also examined the effect of $\mathrm{AB}$ within 60 days of initiating ICIs therapy. However, there were no significant differences between AB use and PFS or OS (data no shown).

In the present study, multivariate analyses identified that $A B$ use and the presence of irAEs are independent prognostic factor for PFS in patients treated with ICIs therapy. The irAEs presumably result from activation of T cells that recognize selfproteins or commensal microorganisms (21) though neither the mechanisms driving these toxicities nor the immunological targets are fully understood so far. Some reports have shown that the presence of irAEs is a potential surrogate and predictive marker of survival in ICIs therapies $(4,22-24)$. Similar findings have been reported in $\operatorname{RCC}(5,25)$. Interestingly, there were no patients with irAEs following ICI therapy in the AB group in our study. Chaput et al. (26) have demonstrated that baseline gut microbiota enriched with
Faecalibacterium and other Firmicutes is associated with both clinical response to ipilimumab and increased occurrence of ipilimumab-induced colitis. Their results have suggested that certain species of bacteria might be associated with the immune activation that could cause irAEs. In our study, ABinduced dysbiosis might change gut microbiota, leading to suppressed activation of immunity and reduced irAEs.

The present study has several acknowledged limitations. First, this is a retrospective study from a single institution and selection bias may exist. In addition, the number of patients in this study was extremely small and the treatment lines in the included patients were heterogenous. Moreover, previous reported biomarkers such as the expression of PDL1 were not examined in this study. Further prospective studies with a larger cohort will be needed to investigate whether $\mathrm{AB}$ use prior to ICIs treatment has a negative impact on PFS and OS in RCC.

In conclusion, our study indicates that use of $\mathrm{AB}$ before ICIs treatment is a predictor of poor ICIs response in metastatic RCC.

\section{Conflicts of Interest}

The Authors declare that there is no conflict of interest regarding this study.

\section{Authors' Contributions}

KU drafted the manuscript. SY contributed to the manuscript. NO, YM, RH and KUemura have contributed to data collection. HK, $\mathrm{KC}, \mathrm{MN}, \mathrm{KN}$ and $\mathrm{MM}$ have performed the clinical follow-up. KU, SS and TI were responsible for the conception and design of this study, interpretation of the data, and critical revision of the manuscript. All Authors read and approved the final manuscript. 
Table III. Univariate and multivariate analysis of progression-free survival.

\begin{tabular}{|c|c|c|c|c|}
\hline \multirow[t]{2}{*}{ Parameter } & \multicolumn{2}{|c|}{ Univariate } & \multicolumn{2}{|c|}{ Multivariate } \\
\hline & HR $(95 \% \mathrm{CI})$ & $p$-Value & HR $(95 \% \mathrm{CI})$ & $p$-Value \\
\hline \multicolumn{5}{|l|}{ Age } \\
\hline$<67$ & 1 & & & \\
\hline$\geq 67$ & $1.210(0.463-3.342)$ & 0.6981 & & \\
\hline \multicolumn{5}{|l|}{ Gender } \\
\hline Male & 1 & & & \\
\hline Female & $1.941(0.666-5.122)$ & 0.2106 & & \\
\hline \multicolumn{5}{|l|}{$\mathrm{T}$ stage } \\
\hline $\mathrm{T} 1 / 2$ & 1 & & & \\
\hline $\mathrm{T} 3 / 4$ & $1.680(0.603-4.444)$ & 0.3083 & & \\
\hline \multicolumn{5}{|l|}{ Grade (Fuhrman) } \\
\hline $\mathrm{G} 1 / 2$ & 1 & & & \\
\hline $\mathrm{G} 3 / 4$ & $1.308(0.430-3.767)$ & 0.6222 & & \\
\hline \multicolumn{5}{|l|}{ LN metastasis } \\
\hline Absent & 1 & & & \\
\hline Present & $1.231(0.390-3.332)$ & 0.7018 & & \\
\hline \multicolumn{5}{|l|}{ Bone metastasis } \\
\hline Absent & 1 & & & \\
\hline Present & $0.565(0.129-1.762)$ & 0.3487 & & \\
\hline \multicolumn{5}{|l|}{ Liver metastasis } \\
\hline Absent & 1 & & & \\
\hline Present & $0.842(0.194-2.584)$ & 0.7830 & & \\
\hline \multicolumn{5}{|l|}{ Number of metastatic sites } \\
\hline One organ & 1 & & & \\
\hline Two or more organs & $1.402(0.519-4.411)$ & 0.5175 & & \\
\hline \multicolumn{5}{|l|}{ IMDC risk classification } \\
\hline Favorable/Intermediate & 1 & & & \\
\hline Poor & $0.945(0.251-3.013)$ & 0.9265 & & \\
\hline \multicolumn{5}{|l|}{ C-reactive protein } \\
\hline$<1.0 \mathrm{mg} / \mathrm{dl}$ & 1 & & & \\
\hline$\geq 1.0 \mathrm{mg} / \mathrm{dl}$ & $1.410(0.537-3.772)$ & 0.4811 & & \\
\hline \multicolumn{5}{|l|}{ irAEs } \\
\hline Absent & 1 & & 1 & \\
\hline Present & $0.122(0.019-0.443)$ & 0.0006 & $0.149(0.023-0.574)$ & 0.0042 \\
\hline \multicolumn{5}{|l|}{$\mathrm{AB}$} \\
\hline Absent & 1 & & 1 & \\
\hline Present & $6.518(1.857-21.416)$ & 0.0048 & $3.830(1.086-12.717)$ & 0.0377 \\
\hline
\end{tabular}

LN: Lymph node; IMDC: International Metastatic Renal Cell Carcinoma Database Consortium; irAE; immune related adverse events; AB: antibiotics.

\section{References}

1 Motzer RJ, Escudier B, McDermott DF, George S, Hammers HJ, Srinivas S, Tykodi SS, Sosman JA, Procopio G, Plimack ER, Castellano D, Choueiri TK, Gurney H, Donskov F, Bono P, Wagstaff J, Gauler TC, Ueda T, Tomita Y, Schutz FA, Kollmannsberger C, Larkin J, Ravaud A, Simon JS, Xu LA, Waxman IM, Sharma P and CheckMate I: Nivolumab versus everolimus in advanced renal-cell carcinoma. N Engl J Med 373(19): 1803-1813, 2015. PMID: 26406148. DOI: 10.1056/ NEJMoa1510665

2 Motzer RJ, Tannir NM, McDermott DF, Aren Frontera O, Melichar B, Choueiri TK, Plimack ER, Barthelemy P, Porta C, George S, Powles T, Donskov F, Neiman V, Kollmannsberger
CK, Salman P, Gurney H, Hawkins R, Ravaud A, Grimm MO, Bracarda S, Barrios CH, Tomita Y, Castellano D, Rini BI, Chen AC, Mekan S, McHenry MB, Wind-Rotolo M, Doan J, Sharma P, Hammers HJ, Escudier B and CheckMate I: Nivolumab plus ipilimumab versus sunitinib in advanced renal-cell carcinoma. $\mathrm{N}$ Engl J Med 378(14): 1277-1290, 2018. PMID: 29562145. DOI: 10.1056/NEJMoa1712126

3 Teishima J, Inoue S, Hayashi T and Matsubara A: Current status of prognostic factors in patients with metastatic renal cell carcinoma. Int J Urol 26(6): 608-617, 2019. PMID: 30959579. DOI: $10.1111 /$ iju.13956

4 Fujii T, Colen RR, Bilen MA, Hess KR, Hajjar J, SuarezAlmazor ME, Alshawa A, Hong DS, Tsimberidou A, Janku F, Gong J, Stephen B, Subbiah V, Piha-Paul SA, Fu S, Sharma P, 
Mendoza T, Patel A, Thirumurthi S, Sheshadri A, MericBernstam $\mathrm{F}$ and Naing A: Incidence of immune-related adverse events and its association with treatment outcomes: The md anderson cancer center experience. Invest New Drugs 36(4): 638646, 2018. PMID: 29159766. DOI: 10.1007/s10637-017-0534-0

5 Ishihara H, Takagi T, Kondo T, Homma C, Tachibana H, Fukuda H, Yoshida K, Iizuka J, Kobayashi H, Okumi M, Ishida H and Tanabe K: Association between immune-related adverse events and prognosis in patients with metastatic renal cell carcinoma treated with nivolumab. Urol Oncol 37(6): 355 e321-355 e329, 2019. PMID: 30935847. DOI: 10.1016/j.urolonc.2019.03.003

6 Routy B, Le Chatelier E, Derosa L, Duong CPM, Alou MT, Daillere R, Fluckiger A, Messaoudene M, Rauber C, Roberti MP, Fidelle M, Flament C, Poirier-Colame V, Opolon P, Klein C, Iribarren K, Mondragon L, Jacquelot N, Qu B, Ferrere G, Clemenson C, Mezquita L, Masip JR, Naltet C, Brosseau S, Kaderbhai C, Richard C, Rizvi H, Levenez F, Galleron N, Quinquis B, Pons N, Ryffel B, Minard-Colin V, Gonin P, Soria JC, Deutsch E, Loriot Y, Ghiringhelli F, Zalcman G, Goldwasser F, Escudier B, Hellmann MD, Eggermont A, Raoult D, Albiges L, Kroemer $G$ and Zitvogel L: Gut microbiome influences efficacy of pd-1-based immunotherapy against epithelial tumors. Science 359(6371): 91-97, 2018. PMID: 29097494. DOI: 10.1126/science.aan3706

7 Elkrief A, El Raichani L, Richard C, Messaoudene M, Belkaid W, Malo J, Belanger K, Miller W, Jamal R, Letarte N, Wong P and Routy B: Antibiotics are associated with decreased progression-free survival of advanced melanoma patients treated with immune checkpoint inhibitors. Oncoimmunology 8(4): e1568812, 2019. PMID: 30906663. DOI: 10.1080/2162402X. 2019.1568812

8 Derosa L, Hellmann MD, Spaziano M, Halpenny D, Fidelle M, Rizvi H, Long N, Plodkowski AJ, Arbour KC, Chaft JE, Rouche JA, Zitvogel L, Zalcman G, Albiges L, Escudier B and Routy B: Negative association of antibiotics on clinical activity of immune checkpoint inhibitors in patients with advanced renal cell and non-small-cell lung cancer. Ann Oncol 29(6): 1437-1444, 2018. PMID: 29617710. DOI: 10.1093/annonc/mdy103

9 Huang XZ, Gao P, Song Y-X, Xu Y, Sun J-X, Chen X-W, Zhao $\mathrm{J}-\mathrm{H}$ and Wang Z-N: Antibiotic use and the efficacy of immune checkpoint inhibitors in cancer patients: A pooled analysis of 2740 cancer patients. Oncoimmunology, 2019. DOI: 10.1080/ 2162402X.2019.1665973

10 Lange K, Buerger M, Stallmach A and Bruns T: Effects of antibiotics on gut microbiota. Dig Dis 34(3): 260-268, 2016. PMID: 27028893. DOI: 10.1159/000443360

11 Common terminology criteria for adverse events (ctcae) v4.0. Available at: http://ctep.Cancer.Gov/protocoldevelopment/electronic _applications/ctc.Htm\#ctc_40. 2018

12 Eisenhauer EA, Therasse P, Bogaerts J, Schwartz LH, Sargent D, Ford R, Dancey J, Arbuck S, Gwyther S, Mooney M, Rubinstein L, Shankar L, Dodd L, Kaplan R, Lacombe D and Verweij J: New response evaluation criteria in solid tumours: Revised recist guideline (version 1.1). Eur J Cancer 45(2): 228247, 2009. PMID: 19097774. DOI: 10.1016/j.ejca.2008.10.026

13 Tumeh PC, Harview CL, Yearley JH, Shintaku IP, Taylor EJ, Robert L, Chmielowski B, Spasic M, Henry G, Ciobanu V, West AN, Carmona M, Kivork C, Seja E, Cherry G, Gutierrez AJ, Grogan TR, Mateus C, Tomasic G, Glaspy JA, Emerson RO, Robins H, Pierce RH, Elashoff DA, Robert C and Ribas A: Pd-
1 blockade induces responses by inhibiting adaptive immune resistance. Nature 515(7528): 568-571, 2014. PMID: 25428505. DOI: 10.1038 /nature 13954

14 Hoos A: Development of immuno-oncology drugs - from ctla4 to pd1 to the next generations. Nat Rev Drug Discov 15(4): 235247, 2016. PMID: 26965203. DOI: 10.1038/nrd.2015.35

15 Pinato DJ, Howlett S, Ottaviani D, Urus H, Patel A, Mineo T, Brock C, Power D, Hatcher O, Falconer A, Ingle M, Brown A, Gujral D, Partridge S, Sarwar N, Gonzalez M, Bendle M, Lewanski C, Newsom-Davis T, Allara E and Bower M: Association of prior antibiotic treatment with survival and response to immune checkpoint inhibitor therapy in patients with cancer. JAMA Oncol, 2019. PMID: 31513236. DOI: 10.1001/jamaoncol.2019.2785

16 Yoon MY and Yoon SS: Disruption of the gut ecosystem by antibiotics. Yonsei Med J 59(1): 4-12, 2018. PMID: 29214770. DOI: $10.3349 /$ ymj.2018.59.1.4

17 Weber D, Hiergeist A, Weber M, Dettmer K, Wolff D, Hahn J, Herr W, Gessner A and Holler E: Detrimental effect of broadspectrum antibiotics on intestinal microbiome diversity in patients after allogeneic stem cell transplantation: Lack of commensal sparing antibiotics. Clin Infect Dis 68(8): 1303-1310, 2019. PMID: 30124813. DOI: $10.1093 / \mathrm{cid} / \mathrm{ciy} 711$

18 Matson V, Fessler J, Bao R, Chongsuwat T, Zha Y, Alegre ML, Luke JJ and Gajewski TF: The commensal microbiome is associated with anti-pd-1 efficacy in metastatic melanoma patients. Science 359(6371): 104-108, 2018. PMID: 29302014. DOI: $10.1126 /$ science.aao3290

19 Gopalakrishnan V, Spencer CN, Nezi L, Reuben A, Andrews MC, Karpinets TV, Prieto PA, Vicente D, Hoffman K, Wei SC, Cogdill AP, Zhao L, Hudgens CW, Hutchinson DS, Manzo T, Petaccia de Macedo M, Cotechini T, Kumar T, Chen WS, Reddy SM, Szczepaniak Sloane R, Galloway-Pena J, Jiang H, Chen PL, Shpall EJ, Rezvani K, Alousi AM, Chemaly RF, Shelburne S, Vence LM, Okhuysen PC, Jensen VB, Swennes AG, McAllister F, Marcelo Riquelme Sanchez E, Zhang Y, Le Chatelier E, Zitvogel L, Pons N, Austin-Breneman JL, Haydu LE, Burton EM, Gardner JM, Sirmans E, Hu J, Lazar AJ, Tsujikawa T, Diab A, Tawbi H, Glitza IC, Hwu WJ, Patel SP, Woodman SE, Amaria RN, Davies MA, Gershenwald JE, Hwu P, Lee JE, Zhang J, Coussens LM, Cooper ZA, Futreal PA, Daniel CR, Ajami NJ, Petrosino JF, Tetzlaff MT, Sharma P, Allison JP, Jenq RR and Wargo JA: Gut microbiome modulates response to anti-pd-1 immunotherapy in melanoma patients. Science 359(6371): 97103, 2018. PMID: 29097493. DOI: 10.1126/science.aan4236

20 Jakobsson HE, Jernberg C, Andersson AF, Sjolund-Karlsson M, Jansson JK and Engstrand L: Short-term antibiotic treatment has differing long-term impacts on the human throat and gut microbiome. PLoS One 5(3): e9836, 2010. PMID: 20352091. DOI: 10.1371/journal.pone.0009836

21 Pitt JM, Vetizou M, Daillere R, Roberti MP, Yamazaki T, Routy B, Lepage P, Boneca IG, Chamaillard M, Kroemer G and Zitvogel L: Resistance mechanisms to immune-checkpoint blockade in cancer: Tumor-intrinsic and -extrinsic factors. Immunity 44(6): 1255-1269, 2016. PMID: 27332730. DOI: 10.1016/j.immuni.2016.06.001

22 Haratani K, Hayashi H, Chiba Y, Kudo K, Yonesaka K, Kato R, Kaneda H, Hasegawa Y, Tanaka K, Takeda M and Nakagawa K: Association of immune-related adverse events with nivolumab efficacy in non-small-cell lung cancer. JAMA Oncol 4(3): 374378, 2018. PMID: 28975219. DOI: 10.1001/jamaoncol.2017.2925 
23 Osorio JC, Ni A, Chaft JE, Pollina R, Kasler MK, Stephens D, Rodriguez C, Cambridge L, Rizvi H, Wolchok JD, Merghoub T, Rudin CM, Fish S and Hellmann MD: Antibody-mediated thyroid dysfunction during t-cell checkpoint blockade in patients with non-small-cell lung cancer. Ann Oncol 28(3): 583-589, 2017. PMID: 27998967. DOI: 10.1093/annonc/mdw640

24 Freeman-Keller M, Kim Y, Cronin H, Richards A, Gibney G and Weber JS: Nivolumab in resected and unresectable metastatic melanoma: Characteristics of immune-related adverse events and association with outcomes. Clin Cancer Res 22(4): 886-894, 2016. PMID: 26446948. DOI: 10.1158/1078-0432.CCR-15-1136

25 Rogado J, Sanchez-Torres JM, Romero-Laorden N, Ballesteros AI, Pacheco-Barcia V, Ramos-Levi A, Arranz R, Lorenzo A, Gullon P, Donnay O, Adrados M, Costas P, Aspa J, Alfranca A, Mondejar R and Colomer R: Immune-related adverse events predict the therapeutic efficacy of anti-pd- 1 antibodies in cancer patients. Eur J Cancer 109: 21-27, 2019. PMID: 30682533. DOI: 10.1016/j.ejca.2018.10.014
26 Chaput N, Lepage P, Coutzac C, Soularue E, Le Roux K, Monot C, Boselli L, Routier E, Cassard L, Collins M, Vaysse T, Marthey L, Eggermont A, Asvatourian V, Lanoy E, Mateus C, Robert $\mathrm{C}$ and Carbonnel F: Baseline gut microbiota predicts clinical response and colitis in metastatic melanoma patients treated with ipilimumab. Ann Oncol 28(6): 1368-1379, 2017. PMID: 28368458. DOI: 10.1093/annonc/mdx 108
Received October 4, 2019

Revised October 14, 2019 Accepted October 15, 2019 